\title{
Habits of Food Consumers in the Post COVID Era
}

\author{
María Aránzazu Sulé Alonso ${ }^{1}$, Tea Rushit ${ }^{2} \&$ Elvira Delgado-Márquez ${ }^{3}$ \\ ${ }^{1}$ Department of Management and Enterprise Economy, University of Léon, Campus de Vegazana, 24007 Léon, \\ Spain \\ ${ }^{2}$ Faculty of Economics Sciences and Business, University of Léon, Campus de Vegazana, 24007 Léon, Spain \\ ${ }^{3}$ Department of Economics and Statistic, University of Léon, Campus de Vegazana, 24007 Léon, Spain \\ Correspondence: María Aránzazu Sulé Alonso, Department of Management and Enterprise Economy, University \\ of Léon, Spain. E-mail: a.sule@unileon.es
}

Received: August 20, 2021

Accepted: September 22, $2021 \quad$ Online Published: September 26, 2021

doi:10.5539/ijms.v13n3p42

URL: https://doi.org/10.5539/ijms.v13n3p42

\begin{abstract}
Humankind has faced various pandemics in history. The food supply chain is one of the foremost vital sectors of the economy, and COVID-19 has had a clear bearing on it from the field to the consumer. In the light of recent challenges in the food supply chain, there is currently considerable concern regarding food production, processing, distribution, and demand. COVID-19 resulted in the movement restrictions of staff, changes in the demands of consumers, closure of food production facilities, restrictive food trade policies, and monetary pressures in the food supply chain.

This study describes the impact of the COVID-19 health crisis on people's interests, opinions, and behaviour towards food. Additionally, an online questionnaire (Spanish population, $\mathrm{n}=232$ ) studied the changes in food shopping habits during the pandemic. To try to cover the whole Léon territory and reach the greatest number of persons through mobile phones, tablets, and computers, the questionnaire was created using the Google Forms tool and distributed using instant messaging apps such as WhatsApp, social media such as Facebook and Twitter, social networking sites such as LinkedIn and ResearchGate, and email through snowball sampling. The statistical analysis was carried out under the SPSS programme. The results are presented in the form of means and distributions. The differences between subgroups have been evaluated using student's t-test. The level of statistical significance used in all cases was $\mathrm{p}<0.05$.

This study is focused on evaluating changes in food consumption habits of the Spanish adult population throughout the COVID-19 lockdown. The study is supported by a web-based survey targeting the adult general population. From this study, we are able to conclude that the studied Spanish adult population is extremely close to from having good healthy dietary habits, considering the Mediterranean Diet as a reference of healthy uptake. An improvement of dietary behaviours throughout the COVID-19 confinement has been discovered. Health-related food selections involved increased intake of fruits, vegetables, and legumes and decreased intake of red meat, alcohol, fried foods, or pastries compared to their pre-pandemic habits.
\end{abstract}

Keywords: confinement, consumer behaviour, covid-19, food habits, Léon, Spain

\section{Introduction}

We are clearly in a society experiencing high-speed, vast changes. The agri-food sector is no stranger to these changes. A few years ago, it was most common for people to buy things in the markets. Then, it common to do so in the neighbourhood shops. Now, we are involved in a model in which it is most common to make a great weekly purchase in the neighbourhood supermarket or even a monthly purchase in the hypermarket of a large shopping centre.

Coronavirus (COVID-19) has caused dramatic disorder for socio-economic norms since first reported in Wuhan, China (Guan et al., 2020; Rowan \& Laffey, 2020). The food industry is doubtlessly one of the hardest-hit sectors from the COVID-19 pandemic. However, despite its challenges, this may be a time to accelerate digital innovation across the industry. By providing trendy channels to concentrate on what customers really need and cultivating meaningful relationships with them, restaurants will maintain, and even strengthen, customer engagement in this new environment. 
Of course, aside from changing the establishment to which we tend to shop for, the food industry has also modified the products themselves and therefore people's shopping habits. Today, consumers have food from anyplace in the world at their fingertips, and due to the chances offered by supply, they also have products at any time of the year. Additionally, the intensive schedules of hypermarkets and their access facilities by automobile make them choose this option in most cases.

Also, the indiscriminate use of phytosanitary products and contamination by excess subscribers have reached the ears of consumers. That is why consumers are increasingly critical and look more at what they buy and eat. The lack of food security means that countries are dependent upon imports but may not be earning sufficient foreign currency to purchase vital imported goods. The post-COVID-19 era conjointly presents equal opportunities to handle global climate change and advance green innovation, matched with driving sustainable food production and security (food industry research, 2019).

This analysis is necessary in a context where marketing is the order of the day, and the strength of it is very large. Advertising campaigns are designed very well to attract the public. The purpose of the study is to shed light on the changes in the food paradigm, presenting an overview of the main effects of the Spanish lockdown on the consumption and food shopping habits of consumers.

Although it was already defined before the coronavirus, the pandemic has reinforced the strategic role of the agri-food sector in supply issues. It has shown some outstanding problems, recalling the need not to delay food treatment any longer and generating some uncertainty regarding the financial resources available (food industry research, 2019).

\section{Literature Review}

\subsection{Food in the 21st Century}

Food plays a principal role in the lifetime of consumers. It is their source of nutrition, and it is economically, socially and culturally significant. Bellisle (2019) noted that food consumption could be a periodic behaviour because of many factors such as time of day, need, sensory stimulation, and social context (Steenkamp, 1993).

The challenges of food in the 21 st century are immense and complex. Providing efficient food production, food safety practices, and property can allow the population to face the essential and growing complexities. The world population will grow from its current 7.7 billion individuals to nearly 10 billion individuals by 2050 , and food production must become a lot of more interconnected. As a result, we will face a growing world population with less farmland to feed everybody. Agricultural and food production should become more economical with less waste to produce sufficient food for the projected population of 2050. Investments in crop management, new ways to expeditiously grow foods, and an improved distribution chain are needed. If not, food security may become a massive public issue around the world due to rising food prices (van de Ligt, 2019).

The study Food and Society in 21st Century Spain, conducted by Fundación MAPFRE's Health Promotion Area in collaboration with the San Pablo University, finds that the Spaniards contemplate that they must always consume food at the same time, be up on what to eat, eat or dine less and eat better for breakfast. Additionally, they claim that they are searching for healthy foods. Spain is a society that shares eating habits; most respondents eat three main meals, principally at home, and eat with one another. In individuals under the age of 30, a growing number of individuals eat and dine looking at TV.

\subsection{Food Consumption in Europe and Spain}

COVID-19 has motivated Europeans to buy higher quality food products associated with improving health. Spanish farmers could benefit from the growing demand for organic food. Spain is one of the EU's leading food exporters, and the country has the largest amount of land dedicated to organic farming in Europe. Not only the health care needs to prevent the spread of the virus, but also the need to strengthen the immune system, suggest a need for functional beverages to these purposes. The pandemic has developed new consumption habits globally that will likely stay (food industry research, 2020).

Tetra Pak (2019) identified that consumers are looking more for healthy foods to strengthen the immune system in old age, and this creates new possibilities of consumer loyalty. Also, the fear to eat outside the home has made the consumers cook healthier. They have more time to dedicate to the kitchen, watching more recipes on YouTube than in cookbooks or following the bloggers who are trying more and more to educate the consumers about leading a green life.

Based on Therrien (2020), some changes in food buying behaviour during COVID-19 include the following:

- Buying in bulk (this is a new trend for customers during COVID-19 to decrease the chance of infection) 
- Increased frozen food purchases (freezing is an effective form of food preservation)

- Increased non-perishable food purchases (non-perishable foods, such as canned goods and dried fruit, have a long shelf life and do not require refrigeration)

- $\quad$ Buying versatile food staples (staple food provides necessary nutrition and is suitable for storage over long periods of time; during the pandemic, many countries have shifted away from lower nutrient density staple foods and towards higher nutrient density staples)

There is a growing recognition of the importance of traditional staple crops in nutrition.

\subsection{Food Consumption Trends in Europe Before and After COVID-19}

According to EAE business school, the web stores that receive the most visits are associated with new food trends, a specific product, or the issues with finding them in a physical store. For instance, organic food stores are growing in Europe. By volume of expenditure on organic food, Germany encompasses a total of 9,478.78 million euros and growth of $10 \%$ year-on-year, followed by France with 6,736 million euros and $21.7 \%$ growth, Italy with 2,644 million euros and 14\% growth, the United Kingdom with 2,460 million euros and a 5.5\% fall, Sweden with 1,950 million euros and no growth, and Spain, which grew by $12.5 \%$.

Therefore, to the extent that physical stores adopt such products that satisfy the consumer, it is possible that visits to such online stores can decrease, increasing in-store purchases. It is an incontrovertible fact that will alter or weigh down the uptrend of online shopping if the arena does not drive it and implement it sufficiently (MPAC, 2017).

Consumption trends before COVID-19 (Rand Corporation, 2020)

- What individuals consume still falls short of dietary pointers.

- High levels of Chinese and Asian food.

- Eating food from outside the house is progressively common.

- Cost and perceived value-for-money.

Consumption trends after COVID-19 (Brand Equity, 2020)

- There is a comeback of home cooking and new "chefs" among the house. YouTube is going to be the new guru.

- Decrease of consuming Chinese and other Asian food.

- Branded commodities can allow safer food buying; new "value-added" and "intermediary" merchandise can take the toil out of cooking and make it pleasant.

- Meal kits are lower priced as a result of numerous individuals having lost their jobs throughout the pandemic.

- There is a decrease in street food consumption, a pickup in take-aways, and higher prospects for home delivery.

- The "new normal" will include less take-out, sparser crowds at restaurants, visible kitchens, no/low-contact technologies, gauntleted and cloaked service, single serve parts.

- Consuming additional probiotics and well-being ingredients have increased.

- Sustainable merchandise has increased.

\subsection{Upcoming New Trends}

Since the beginning of stay-at-home orders during the pandemic, food has been a frequent, varied topic of discussion (Debroff, 2020).

- Grocery looking, a speed exercise in anxiety

During the pandemic, customers have chosen additional shopping online with home delivery or store pickup. This trend offers grocery stores and the brands that sell through them an opportunity to convert additional shoppers through online grocery for home delivery or grocery pickup.

- Changes in family eating and snacking habits

Eating habits have modified within the time we have been staying at home. Individuals tend to eat more to deal with stress or tedium and to do so immediately.

- Cooking up a storm at home 
With an ensuing surplus of free time, many individuals are latching onto preparation as a way to feel safe. Being stuck at home has led to an increase in home-cooked meals and formula experimentation for many.

- Calling all kitchen gadgets

Kitchen devices have seen growth throughout the stay-at-home period. With customers spending longer periods of time in food preparation and baking, many people have already purchased small new kitchen appliances.

\section{- A takeout shakeout}

Needing to prepare food seven days every week, thrice every day, for an extended amount of your time has several customers turning to somebody else to assist with the preparation. Takeout and delivery from restaurants provide a welcome break.

\subsection{Food Consumption Habits in Spain}

There are many food consumptions habits that have been changing or emerging in recent years, especially in the COVID-19 crisis. Many families have been rethinking their consumption habits, adapting them to the new situation, and thus creating new food trends.

\section{- Eating healthy}

One of the main changes in consumer habits that has occurred in recent years is taking a step towards healthy eating, and it is undeniable that more and more adults and young people worry about their diet and try to take care of themselves. Derived from this change in habits, going from "junk" to healthy food, they have created new trends, such as the desire for fresh products and the decrease in ultra-processed foods. This trend is already reflected in supermarkets in which the surfaces aimed at fresh products have been increased to offer more products.

\section{- Convenience}

The crisis caused by COVID-19 and the related lifestyle changes in the lifestyles have made more and more people seek convenience in their routines and shopping. This directly affects people's diets and habits, making life fast-paced and leading us to spend less time shopping and to demand faster and more convenient food service.

Thus, in the last year, the great beneficiaries of these routines have been supermarkets (those located close to homes) and small neighbourhood convenience stores offering grocery products. Families no longer feel like spending a whole morning in a hypermarket, and students do not have time to invest hours doing shopping.

According to the Report on Food Consumption in Spain (2019) carried out by the Ministry of Agriculture, Fisheries and Food, supermarkets represent $48.2 \%$ of food purchases, and visits to convenience stores have grown thanks to the increase in consumption of fresh produce $(29.9 \%)$.

\section{- $\quad$ E-commerce}

Because of the accelerated pace of life and pandemic-related confinement, more and more consumers order food over the internet. According to this study "E-commerce in Europe," Spain was one of the country's most severely affected by the 2008 financial crisis, and a number of fiscal measures to promote the economy were implemented. But despite the economic challenges, e-commerce has grown sharply in recent years, and the number of e-commerce consumers has steadily increased.

Spanish e-commerce consumers have the second highest expectations for fast delivery (the Netherlands is number one). One in four consumers expects to receive a product purchased online within one to two days, and willingness to pay for next-day delivery is high at $41 \%$. Flexible delivery is also high; $56 \%$ state that it is important to be able to decide the time at which the product is to be delivered. This trend is probably related to the fact that Spanish consumers want home delivery in the evening to a greater extent than consumers in other countries. Regarding payment methods, credit and debit cards as well as payment services such as PayPal, account for a remarkable $90 \%$ of people's preferred payment method. Italy and Spain are among the countries where e-commerce has developed most rapidly in recent years (Postnord, 2019).

\section{- Rapidity}

Another habit that has spread in Spain is the speed of the time given to eating, new consumer trends have emerged, such as prepared meals or the use of apps that distribute meals from your favourite restaurants quickly.

According to Organization of consumers and users (2019), 36\% of Spaniards already used food delivery apps as 
one more part of their diets, and the numbers were expected to triple by 2020 . To this day and due to fear caused by the pandemic, these new "Delivery" systems have become more widespread. Along the same lines, restaurants are already adapting to this new trend of food consumption by offering food delivery.

\section{- Environmental concern}

As a result of concern for the environment and the effects of the food industry on it, trends have emerged such as ecological products that are becoming more popular and have an increased presence in supermarkets. They are even beginning to create their own establishments for them.

According to a report by AECOC (Association of Manufacturers and Distributors), Spain was positioned in 2017 as one of the main consumer countries of ecological and bioproducts.

According to AESCO (Association of Entrepreneurs and Supermarkets Ecological), a report carried out by the Ministry of Agriculture in 2019 indicates that the ecological sector in Spain maintains constant growth with a remarkable economic, social and environmental impact. Also derived from this concern, trends emerge such as the return to natural products obtained directly from producers without conversion and chemical processes.

\section{The Food Consumer Typologies}

A consumer may refer to a person who regularly consumes a particular product. Consumption refers to the use or purchase of products of different specialties. They are marketed to meet the basic needs and desires of individuals (Consumption Research, 2020).

\section{- Consumer typologies}

According to the "Green Revolution (2019)", consumption of organic and healthy products has been increasing for several years. For instance, the Spanish population represented by $9.9 \%$ over the age of 18 is vegetarian, vegan, or flexitarian.

$\checkmark$ Vegetarians (1.5\% of the Spanish population): People who limit their diet to plant-based meals, although they include some products derived from animals. They also reject the use of leathers and furs for the manufacture of clothing.

$\checkmark$ Vegans (0.5\%): People whose way of understanding life rejects any type of animal exploitation. That is, in addition to not eating meat or fish, they also do not consume eggs, milk, or honey.

$\checkmark$ Flexitarians (7.9\%): People who add animal protein to their diet. Despite being the least well-known term, it is the largest of these population segments. These people base their diet on a vegetarian diet, but for various reasons, they also consume some products of animal origin: birds and meats, seafood and fish, although not necessarily all of them.

$\checkmark$ Eco-friendly consumers: People for follow ecological consumption, starting with fresh produce and an increase of health food categories. The main reason for the consumption of organic products is understanding that these products help people lead a healthier life. The absence of synthesis chemicals and the taste are the main motivations for the consumption of organic products.

\subsection{Delivery Wishes and Needs Before and During COVID-19}

According to this European research "E-commerce and distribution channels (2020)" these are some elements on which COVID-19 had a big impact.

$\checkmark$ The environment: The rise of e-commerce is a problem for the environment. The environment is not a big concern for delivery companies (yet), and these companies do not offer additional green delivery services. Although more than half of online shoppers say they are concerned that the rise of e-commerce is a problem for the environment, only $13 \%$ is willing to pay extra shipping costs for their order to be delivered in a $\mathrm{CO} 2$ neutral way, and only $5 \%$ claims to choose one delivery company over another because they offer green delivery options.

$\checkmark \quad$ Willingness to wait for delivery: COVID-19 led to a lot of challenges for delivery companies as well. Due to various measurements in different countries and an increase in the number of orders, delivery delays have been hard to avoid. Before the pandemic, European online shoppers expected to have an order delivered in about three days and were willing to wait a maximum of 4.4 days. The pandemic has made consumers more patient: the average maximum number of days they are now willing to wait for standard delivery went up to 6.4 . More than a third is willing to wait 6-9 days to receive their order. 


\subsection{Commercialization of the Food Sector in Spain}

In the age of new technologies, food items account for a percentage of sales made through e-commerce. Matching the rest of the sectors in the technological field is one of the great challenges for the agri-food sector. The agri-food industry is the first economic sector in Spain. A large part of the sector has already begun to implement and apply new technologies to production processes and value chain management.

Social distancing, mobility restrictions, and health security measures have made digital tools very important. Not only the technology was more frequently used, but online spending has also increased for $48 \%$ of Spanish consumers. Spaniards have increased their online spending during the pandemic, communicating more by messaging and social media tools with brands and shopping at local stores they previously did not know (Rodríguez, 2019).

According to the European Buyer's Study prepared by Information resources, Inc (an expert in big data and technology for the consumer industries) in Spain, $74 \%$ of consumers show their preference for the purchase of products from companies with sustainable packaging practices, whereas the percentage rises to $78 \%$ in terms of the environment. Spain with $40 \%$ and Greece with $36 \%$ are the countries with the highest preference for the purchase of fresh locally produced food, compared to the $32 \%$ average among all European countries.

Kantar recalls that $65 \%$ of consumers prefer to buy products manufactured in their country of origin. Furthermore, $73 \%$ of Spaniards prefer local consumption. In this sense, the consumption of fresh and local food has skyrocketed during COVID-19-related confinement. According to data from the Ministry of Agriculture, Fisheries and Food, the consumption of meat and vegetables has experienced growth of over $30 \%$ during quarantine.

\subsection{Buying from Groceries Online}

The market is where buyers and sellers gather to make the purchase and sale of different products and/or services, and it does not have to be a physical site. Today, there are many channels that allow people to buy and sell without the buyer and seller knowing each other. In this sense, the internet has been a breakthrough because virtually everyone worldwide is connected through it, and e-commerce is on the rise (Rodríguez, 2019).

- Transaction security is one of the key aspects for consumers to continue to use e-commerce as a purchasing channel [CEC (The European Consumer Center), 2019].

- The fundamental element of buying online is comfort, followed by cheaper price and product availability, offers/discounts for having more variety of products, home delivery, and the possibility to buy at any time (CEC, 2019).

- As shown in the graph, in the first five years, there is a small percentage of individuals purchasing groceries online due to people's insecurities.

- From 2014 to 2019, we see a gradual increase of online grocery purchasing, and e-commerce has had a great impact on people's lives. In 2019, 15\% of individuals purchased groceries online in Spain, reflecting the highest percentage in this ten-year period.

- In 2020, as a consequence of the pandemic, there was a boom in online shopping. 


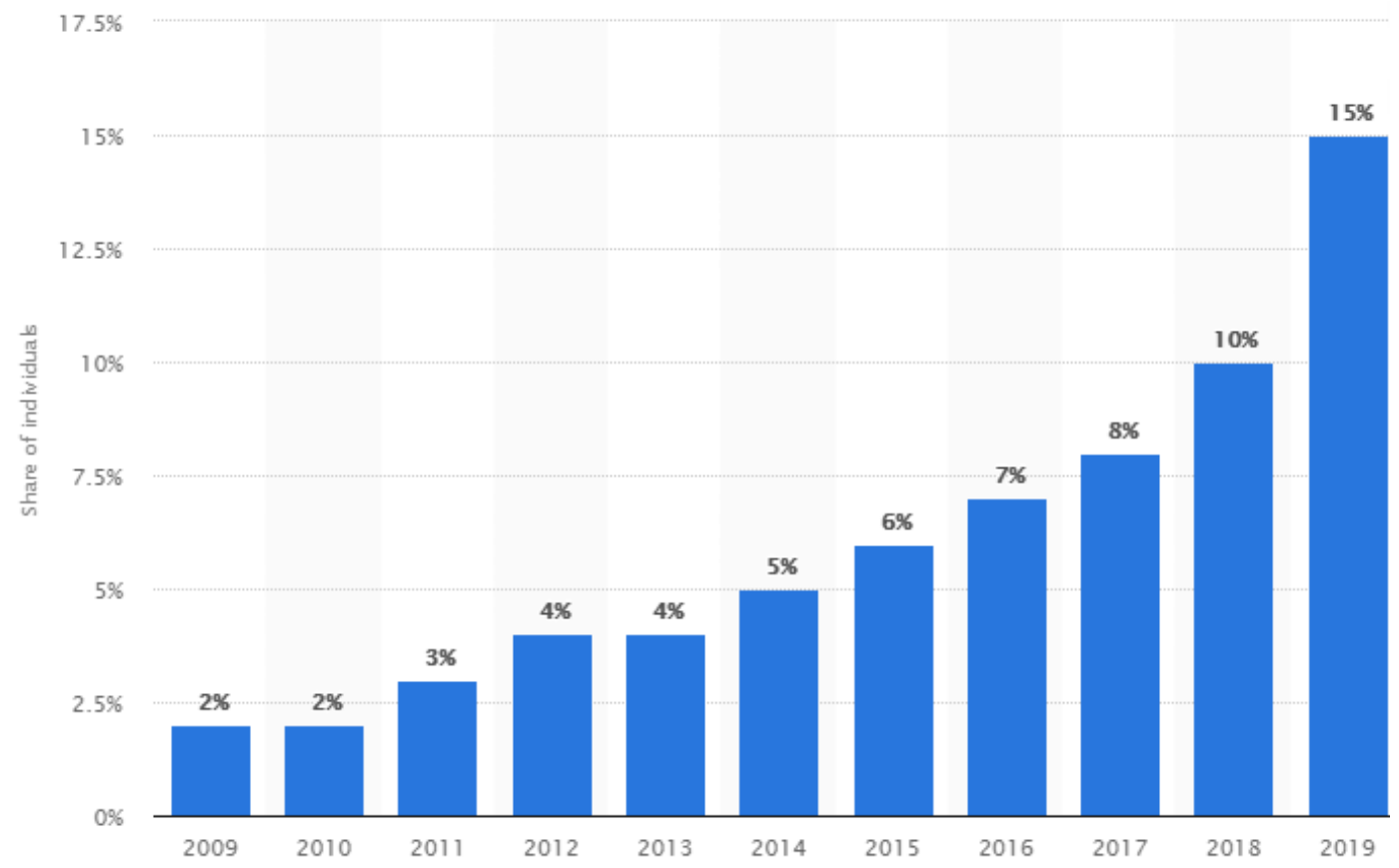

Figure 1. Share of individuals who purchased food or groceries online in Spain from 2009 to 2019

$\begin{array}{llllll}\text { Source: } & \text { (C) } & \text { Statista } & \text { 2021, } & \text { retrieved }\end{array}$

https://www.statista.com/statistics/700640/share-of-individuals-who-purchased-groceries-online-in-spain/

\subsection{The Sale of Local Food}

According to Honeycutt (2017) there is no formal definition of the term "local food." However, one common definition of local food is food grown within 100 miles of its purpose of sale or consumption. Here are some reasons why it is so important to buy local food:

a) It is better for our health, fresher, and tastes better.

b) Locally grown produce could be safer, and local farms offer more variety.

c) Food from local producers may contain fewer or no pesticides.

d) Eating more local food reduces $\mathrm{CO}_{2}$ emissions.

e) Local food helps preserve green space.

f) Supporting local food aids your local economy.

g) Local food creates community and affiliation.

Increasing consumption of local products is one of the trends over the past decade and has increased during the pandemic. For this reason, the internet platform Mercado Local began so that producers and consumers could facilitate the sale of local products.

During confinement and also the monumental economic difficulties faced by smallholder farmers engaged in the food sector, this new project seeks to promote the local economy, responsible consumption, fair trade, sustainability, and the environment. Consumers will contact the seller directly by phone, WhatsApp, or through a contact form to agree with the seller on the delivery and the method of payment.

This new project seeks to promote the local economy, responsible consumption, fair trade, sustainability, and the environment. In the case of local producers, Mercado Local offers the possibility to sell its products directly without intermediaries. On the platform, any local producer can sell their products.

The platform may be utilized by anyone who has a family garden and at any given time. Additionally, they will advertise their products without charge and find their ads revealed on the portal, where they will have their personal page that lists all the products they have for sale (Food Retail Research, 2020).

\subsection{Spanish Platforms of Healthy Food}

According to Varela (2020), these are some Spanish platforms where you can find healthy local food. 


\section{DO EAT!}

Food delivery has become one of the favourite alternatives of Spaniards, and healthy options are increasingly demanded on weekdays. During 2019, Spaniards stopped cooking 41 million lunches and dinners in favour of quick and comfortable options such as delivery, according to a report by Kantar Worldpanel. During the week, $77 \%$ of orders at midday are healthy dishes, according to Glovo data. Do Eat! has created a healthy food menu and is famous for its "fast good" offer in Madrid. It offers more than 19 dishes, 7 desserts, and a traditional variety of juices and drinks, so the consumer has all the necessary nutrients for a complete and balanced meal both at home and at the office.

\section{foodStories}

The combination of the increased popularity of healthy eating and a lack of time led to foodStories, a Spanish start-up that proposes to the consumer different menus every day and takes home the ingredients in the correct amounts to prepare each recipe, avoiding food waste. Ingredients are delivered in recyclable and sustainable glass containers.

\section{Foos}

This platform, created in Seville at the end of 2018, is dedicated to the sale of homemade food aimed at offices. It has a business model aimed at both private consumers and Sevillian companies. However, during COVID-19, with offices closed and teleworking in operation, Foos changed the focus of its business. They wanted to help seniors, single-parent families, and anyone who was afraid or struggling to go shopping and began supporting local establishments. In addition to its social commitment, Foos also takes into account its carbon footprint and uses organic and compostable packaging.

\section{Materials and Methods}

\subsection{Data Collection}

The data collection was carried out with an online survey with the support of Google Forms, an online data collection software during the month of March 2021. The target population are consumers over 18 years old that live in the city of León. The survey was distributed via email and social networking sites.

\subsection{Questionnaire Design}

The questionnaire being carried out begins with an introduction about the research scope and its objectives; it asks for collaboration and guarantees the anonymity and confidentiality of the respondent's answers. This questionnaire comprises 5 blocks with a total of 32 question. The blocks are as follows: lifestyle, food purchase habits, behavior of food consumption, changes in eating habits and lifestyle, and demographics and personal characteristics.

\subsection{Pilot Test and Sample}

Before launching the survey, a pilot test was conducted to ensure questions' clarity and reduce possible errors. The chosen sample for the pilot test consisted of 30 persons that are students and professors in León University. After implementation and analysis of the pilot study and based on some recommendations for improvement, modifications were made to the questionnaire, which included wording and formatting, to make it easier to understand and to yield more accurate answers.

Once the best design of the questionnaire was established, the final version survey was created, from which 232 valid answers have been obtained. With this number of questionnaires and a $95 \%$ confidence interval, the sampling error was $6.92 \%$. Socio-demographic characteristics of individuals surveyed are shown on Table 1. 
Table 1. Socio-demographic characteristics

\begin{tabular}{|c|c|c|}
\hline Sample size & & $232(100 \%)$ \\
\hline \multirow[t]{2}{*}{ Gender } & Male & $36 \%$ \\
\hline & Female & $64 \%$ \\
\hline \multirow[t]{6}{*}{ Age } & $18-24$ & $17 \%$ \\
\hline & $25-34$ & $15 \%$ \\
\hline & $35-44$ & $23 \%$ \\
\hline & $45-54$ & $28 \%$ \\
\hline & $55-70$ & $12 \%$ \\
\hline & $>70$ & $5 \%$ \\
\hline \multirow[t]{4}{*}{ Level of study } & Compulsory basic education & $12 \%$ \\
\hline & Professional Training & $13 \%$ \\
\hline & University level & $44 \%$ \\
\hline & Postgraduate studies & $31 \%$ \\
\hline \multirow[t]{5}{*}{ Marital status } & Single & $41 \%$ \\
\hline & Married & $45 \%$ \\
\hline & Separated & $2 \%$ \\
\hline & Widowed & $4 \%$ \\
\hline & Divorced & $8 \%$ \\
\hline Sample size & & $232(100 \%)$ \\
\hline \multirow[t]{7}{*}{ Occupation } & Student & $20 \%$ \\
\hline & Employed worder & $53 \%$ \\
\hline & Autonomus & $10 \%$ \\
\hline & Unemployed & $4 \%$ \\
\hline & Retired & $8 \%$ \\
\hline & House work people & $3 \%$ \\
\hline & Others & $3 \%$ \\
\hline \multirow[t]{5}{*}{ Monthly income } & Less than $950 €$ & $32 \%$ \\
\hline & 950 to 1500 & $24 \%$ \\
\hline & 1501 to 2000 & $20 \%$ \\
\hline & 2001 to 2500 & $10 \%$ \\
\hline & More than 2500 & $14 \%$ \\
\hline
\end{tabular}

Source: Own elaboration.

The majority of the sample are woman, represented by $64 \%$. The group age between $45-54$ years old represented the majority, with $27.9 \%$ of the total sample (Table 1 ).

Regarding the level of education, a plurality of the participants (43.5\%) had university education, and marital status was predominantly those who are married common-law or living with a partner (45.3\%).

In terms of employment, the statistical analysis shows that the majority (53\%) of respondents are employed, in terms of monthly income. The majority (31.9\%) of respondents have a monthly income of less than 950 euros.

\section{Bivariate Analysis: Hypothesis Testing (Chi-Squared and ANOVA)}

\subsection{Chi-Squared Test}

This test is used to determine whether there is a significant association between two variables. For our study a chi-squared test $\left(\chi^{2}\right)$ was used to search whether a statistically significant relationship exists between the dependent variables (social habits, food consumption) with the independent variables (gender, age). The hypotheses proposed for this factor are as follows:

\section{- Gender}

The hypotheses proposed for this factor are:

\section{1) Social Habits:}

H0: Gender and social habits are independent.

H1: Gender and social habits are not independent.

Most women and most men have answered that after the social isolation, their habits have changed (Table 2). 
Table 2. Counts for social habits by gender

\begin{tabular}{llll}
\hline & Gender & \multicolumn{2}{c}{ Total } \\
\cline { 2 - 3 } & Women & Men & \\
\hline Social habits & $\mathbf{1 3 6}$ & $\mathbf{7 1}$ & 207 \\
& 13 & 10 & 23 \\
Total & 149 & 81 & 230 \\
\hline
\end{tabular}

\section{2) Food Consumption:}

H0: Gender and food consumption are independent.

H1: Gender and food consumption are not independent.

In terms of food consumption, it can be seen that there is a clear difference between the two genders. The majority of women (77 out of 149 in total) chose that there was no change in the consumption of their meals, whereas the majority of men responded that there were changes in the consumption of meals (51 out of 81 in total).

Table 3. Counts for food consumption by gender

\begin{tabular}{llll}
\hline & Gender & Total \\
\cline { 2 - 3 } & Women & Men & \\
\hline Food consumption & 72 & $\mathbf{5 2}$ & 124 \\
& $\mathbf{7 7}$ & 29 & 106 \\
Total & 149 & 81 & 230 \\
\hline
\end{tabular}

From Table 4, the p-value for social habits is 490 in the two-tailed test. Because the p-value is greater than the significance level of 0.05 , it cannot be concluded that the observed data are statistically different from the expected values, and consequently, social habits and gender are independent (Fail to reject $\mathrm{HO}$ ).

Regarding the food consumption, the p-value for social habits is .027 in the two-tailed test. Because the obtained p-value from the two-tailed test is less than the significance level (0.05), we reject the null hypothesis. Thus, we conclude that there is a relationship between gender and food consumption.

Table 4. Chi-square test results for gender

\begin{tabular}{lllll}
\hline & Pearson Chi-Square Value & df & Asymptotic Sig. (2-Sided) & Exact Sig. (2-Sided) \\
\hline Social Habits & $\mathbf{. 6 4}^{\mathrm{a}}$ & 1 & .382 & $\mathbf{0 . 4 9 0}$ \\
Food Consumption & $\mathbf{5 . 3 2 3}^{\mathrm{b}}$ & 1 & .021 & $\mathbf{. 0 2 7}$ \\
\hline
\end{tabular}

The strength of this relationship between gender and food consumption has been estimated using Phi and Cramer's V values. The outcome has given the same value with different signs where Phi $=-.152$ and Cramer's $\mathrm{V}=.152$. According to tables of interpretation and the value obtained, we can say that the strength of association between gender and food consumption is weak.

Table 5. Phi and Cramer's V values for gender and food consumption

\begin{tabular}{llll}
\hline & & Value & Approx. Sig. \\
\hline Nominal by Nominal & Phi & -.152 & .021 \\
& Cramer's V & .152 & .021 \\
N of Valid Cases & & 230 & \\
\hline
\end{tabular}

- Age

The hypotheses proposed for this factor are as follows:

\section{1) Eating habits:}

H0: Age and eating habits are independent. 
H1: Age and eating habits are not independent.

Most people of all age groups answered that eating habits did not change during the pandemic period, except for those over 70 years old, most of which answered that eating habits changed during the period of pandemic (Table $6)$.

Table 6. Counts for eating habits with age

\begin{tabular}{llllllll}
\hline & Age (years) & \multicolumn{2}{l}{ Total } \\
\cline { 2 - 7 } & 18 to 24 & 25 to 34 & 35 to 44 & 45 to 54 & 55 to 70 & Over 70 & 84 \\
Changes in eating habits & 10 & 16 & 23 & 22 & 6 & 7 & 148 \\
& 30 & 19 & 30 & 43 & 21 & 5 & 232 \\
\hline
\end{tabular}

\section{2) Snack consumption:}

H0: Age and snack consumption are independent.

H1: Age and snack consumption are not independent.

Table 7. Counts for snack consumption with age

\begin{tabular}{llllllll}
\hline & Age (years) & & & & Total \\
\cline { 2 - 8 } & 18 to 24 & 25 to 34 & 35 to 44 & 45 to 54 & 55 to 70 & Over 70 & 110 \\
\hline Changes in snack consumption & 24 & 20 & 26 & 26 & 10 & 4 & 121 \\
& 16 & 14 & 27 & 39 & 17 & 8 & 231 \\
\hline
\end{tabular}

In terms of snack consumption, it can be seen that there is a clear difference between two age groups. Most of the two younger age groups, 18-24 years and 25-34 years, answered that since the beginning of the pandemic, there have been changes in their nutrition and snack consumption. By contrast, other age groups have responded that since the beginning of the pandemic, there have been no changes in their snack consumption.

Table 8. Chi-squared test results for age

\begin{tabular}{lllll}
\hline & Pearson Chi-Square Value & df & Asymptotic Sig. (2-Sided) & Exact Sig. (2-Sided) \\
\hline Eating Habits & $9.717^{\mathrm{a}}$ & 5 & .084 & 0.107 \\
Snack Consumption & $7.920^{\mathrm{b}}$ & 5 & .161 & 0.205 \\
\hline
\end{tabular}

From Table 8, the p-value for eating habits is .107 in the two-tailed test. Because the p-value is greater than the significance level of 0.05 , it cannot be concluded that the observed data are statistically different from the expected values, and consequently, eating habits and age are independent (Fail to reject HO).

In terms of snack consumption, the p-value is .205 in the two-tailed test. The p-value is greater than the significance level of 0.05 . Therefore, age and snack consumption are independent (Fail to reject H0).

\subsection{One-Way Analysis of Variance (ANOVA)}

This test is used to determine whether there are any statistically significant differences between the means of two or more independent groups.

\section{A. Income}

The ANOVA test was conducted to investigate the impact of income on eating habits and food consumption. Respondents have been divided into six groups according to their monthly income.

The hypotheses proposed for income are as follows:

\section{1) Eating Habits:}

H0: Income and eating habits are independent.

H1: Income and eating habits are not independent. 
An ANOVA test regarding the relation between monthly income and eating habits showed that there is no statistically significant difference at $\mathrm{p}<.05$, where $\mathrm{F}=(2.204)<5=\mathrm{F}_{\mathrm{k}}$ and sig $=.070>0.05=\mathrm{p}$. Therefore, the null hypothesis stating that monthly income and eating habits are not related is accepted.

Table 9. One way ANOVA test of the dependent variables with monthly incomes

\begin{tabular}{lllllll}
\hline Dependent variables & & Sum of Squares & df & Mean Square & F & Sig. \\
\hline Changes in the financial situation affecting & Between Groups & 1.541 & 4 & .385 & $\mathbf{2 . 2 0 4}$ & .070 \\
eating habits & Within Groups & 35.328 & 202 & .175 & & \\
& Total & 36.870 & 206 & & & \\
\hline
\end{tabular}

\section{2) Food Consumption:}

H0: Income and food consumption are independent.

H1: Income and food consumption are not independent.

Table 10. One way ANOVA test of the dependent variables with monthly incomes

\begin{tabular}{lllllll}
\hline Dependant variables & & Sum of Squares & df & Mean Square & F & Sig. \\
\hline Changes in the consumption of your meals & Between Groups & 6.649 & 4 & 1.662 & 7.411 & .000 \\
& Within Groups & 50.920 & 227 & .224 & & \\
& Total & 57.569 & 231 & & & \\
\hline
\end{tabular}

ANOVA results revealed that there is a statistically significant difference at the $\mathrm{p}<.05$ level in food consumption for the five groups of monthly income $\left(\mathrm{F}_{\mathrm{v}}=7.411>5=\mathrm{F}_{\mathrm{k}}\right.$, sig $\left.=.000<0.005=\mathrm{p}\right)$. Therefore, the null hypothesis stating that food consumption and monthly income are not related is rejected.

Having rejected the null hypothesis in the ANOVA test, it is necessary to perform a post-hoc test. A Tukey test has been carried out to identify which income levels have had differences in food consumption during the pandemic. According to post-hoc comparisons in Table 11, the main significant differences exist between income levels of the following:

1) $[2001,2500]$ y $[0,950]$.

2) $[2001,2500]$ y $[1501,2000]$.

3) $[2501]$ y $[1501,2000]$

Table 11. p-values for Tukey test

\begin{tabular}{llllll}
\hline & {$[\mathbf{0 , 9 5 0}]$} & {$[\mathbf{9 5 1}, \mathbf{1 5 0 0}]$} & {$[\mathbf{1 5 0 1}, \mathbf{2 0 0 0}]$} & $\mathbf{[ 2 0 0 1 , \mathbf { 2 5 0 0 } ]}$ & {$[\mathbf{2 5 0 1}, \mathbf{)}$} \\
\hline$[\mathbf{0 , 9 5 0 ]}$ & & 0.575 & 0.640 & 0.004 & 0.209 \\
{$[\mathbf{9 5 1}, \mathbf{1 5 0 0}]$} & 0.575 & & 0.070 & 0.136 & 0.918 \\
{$[\mathbf{1 5 0 1}, \mathbf{2 0 0 0 ]}$} & 0.640 & 0.070 & & 0.000 & 0.019 \\
{$[\mathbf{2 0 0 1}, \mathbf{2 5 0 0}]$} & 0.004 & 0.136 & 0.000 & & 0.601 \\
{$[\mathbf{2 5 0 1}]$} & 0.209 & 0.918 & 0.019 & 0.601 & \\
\hline
\end{tabular}

\section{B. Occupation}

The ANOVA test was conducted to investigate the impact of income on food consumption and snack consumption.

The hypotheses proposed for income are as follows:

\section{1) Food Consumption:}

H0: Occupation and food consumption are independent.

H1: Occupation and food consumption are not independent.

An ANOVA test regarding the relation between occupation and food consumption showed that there is no statistically significant difference at the $\mathrm{p}<.05$, where $\mathrm{F}=2.266<5=\mathrm{F}_{\mathrm{k}}$ and $\mathrm{sig}=.052>0.05=\mathrm{p}$. Therefore, the null hypothesis stating that occupation and food consumption are not related is accepted. 
Table 12. On-way ANOVA test of the dependent variables with occupation

\begin{tabular}{llllll}
\hline & Sum of Squares & $\mathrm{df}$ & Mean Square & F & Sig. \\
\hline Between Groups & 3.280 & 6 & .547 & $\mathbf{2 . 2 6 6}$ & .052 \\
Within Groups & 54.289 & 225 & .241 & & \\
Total & 57.569 & 231 & & & \\
\hline
\end{tabular}

\section{2) Snack consumption:}

H0: Occupation and snack consumption are independent.

H1: Occupation and snack consumption are not independent.

ANOVA results revealed that there is a statistically significant difference at the $p<.05$ level in snack consumption for the seven groups of occupations $\left(\mathrm{F}_{\mathrm{v}}=2.183<5=\mathrm{F}_{\mathrm{k}}\right.$, sig $\left.=.061>0.05=\mathrm{p}\right)$. Therefore, the null hypothesis stating that occupation and snack consumption are not related is accepted.

Table 13. One-way ANOVA test of the dependent variables with occupation

\begin{tabular}{llllll}
\hline & Sum of Squares & df & Mean Square & F & Sig. \\
\hline Between Groups & 3.183 & 6 & .531 & $\mathbf{2 . 1 8 3}$ & .062 \\
Within Groups & 54.436 & 224 & .243 & & \\
Total & 57.619 & 230 & & & \\
\hline
\end{tabular}

\subsection{Multiple Correspondence Analysis}

Table 14 describes dimensions that allow us to see which variables on the axes are the most linked, i.e., which categorical variables and categories describe the best each axis. We have merged the most useful variables of this study into only two dimensions.

Table 14. Dimension description

\begin{tabular}{llllll}
\hline Dimension 1 (12.5\%) & \multicolumn{5}{l}{ Dimension 2 (9.5\%) } \\
\hline Variable & $\mathbf{R 2}$ & p-value & Variable & R2 & p-value \\
\hline healthy food & 0.4100 & 0.0000 & gym & 0.3241 & 0.0000 \\
soc_habits & 0.3644 & 0.0000 & bike & 0.2269 & 0.0000 \\
shopping & 0.3158 & 0.0000 & other & 0.2193 & 0.0000 \\
run & 0.1993 & 0.0000 & shopping & 0.2044 & 0.0000 \\
work & 0.1951 & 0.0000 & tennis & 0.1007 & 0.0000 \\
walk & 0.1373 & 0.0000 & run & 0.0840 & 0.0000 \\
swim & 0.1065 & 0.0000 & soc_habits & 0.0819 & 0.0000 \\
tennis & 0.0816 & 0.0000 & confined & 0.0790 & 0.0000 \\
other & 0.0446 & 0.0012 & swim & 0.0564 & 0.0003 \\
confined & 0.0211 & 0.0268 & healthy food & 0.0256 & 0.0147 \\
\hline
\end{tabular}

Source: Own elaboration.

As shown in the Table 14 for dimension 1, healthy food, social habits, and buying behaviour (i.e., shopping) represent the higher coefficient of determinant $\mathrm{R}^{2}$. Meanwhile, for dimension number 2, the variables like gym, bike, and the components cited as "other" represent the higher coefficient of determinant $\mathrm{R}^{2}$ compared with the other variables.

The components of dimension 1 explain $12.5 \%$ of the variation in the data, and the components of dimension 2 explain $9.5 \%$ of the variation in the data.

In Figure 2, the screen plot shows that the eigenvalues start to form a straight line after the third principal component. The first two dimensions account for most of the variance in the data, and this is the reason we decided to do this kind of analysis. 


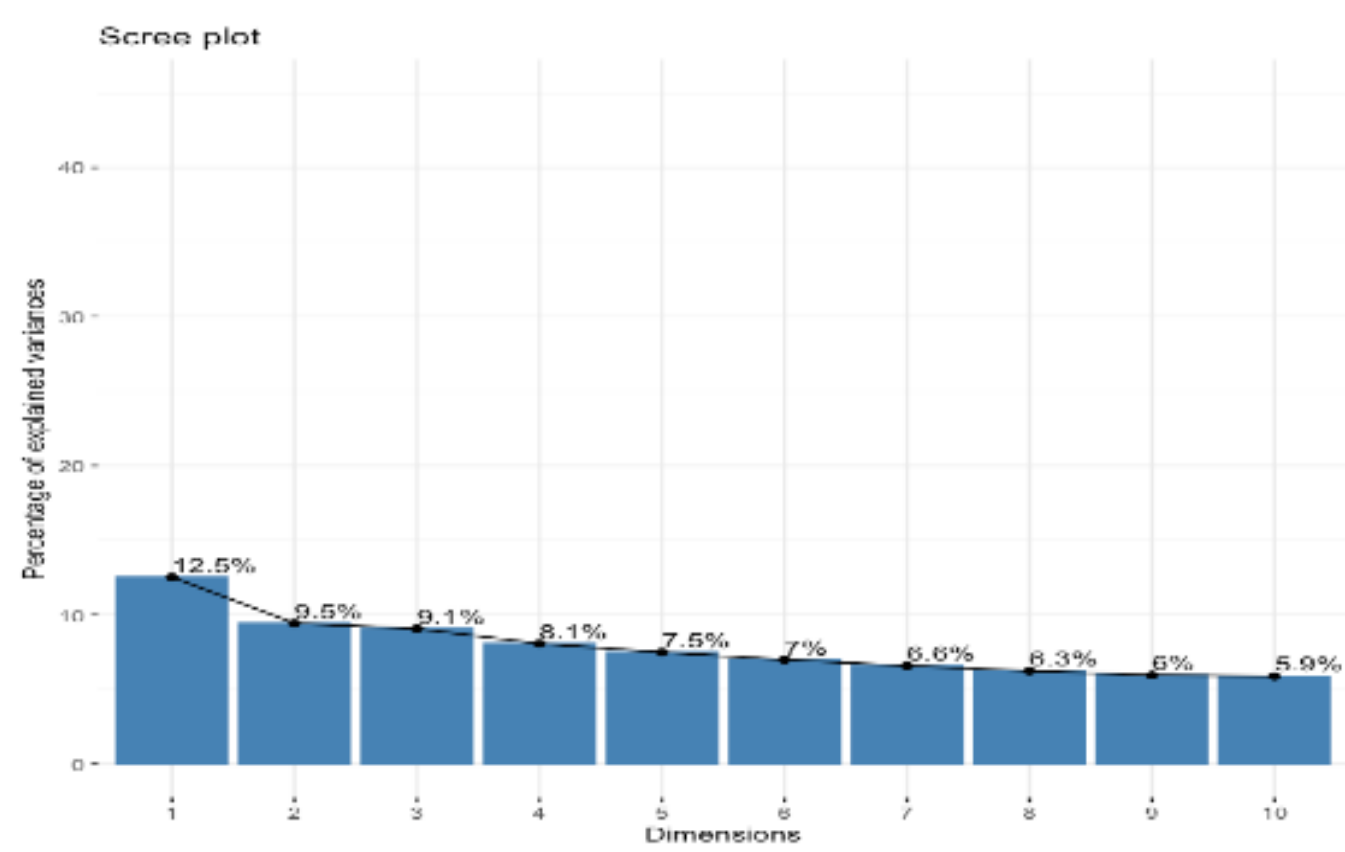

Figure 2. Visualize the eigenvalues/variances of the dimensions

Source: Own elaboration.

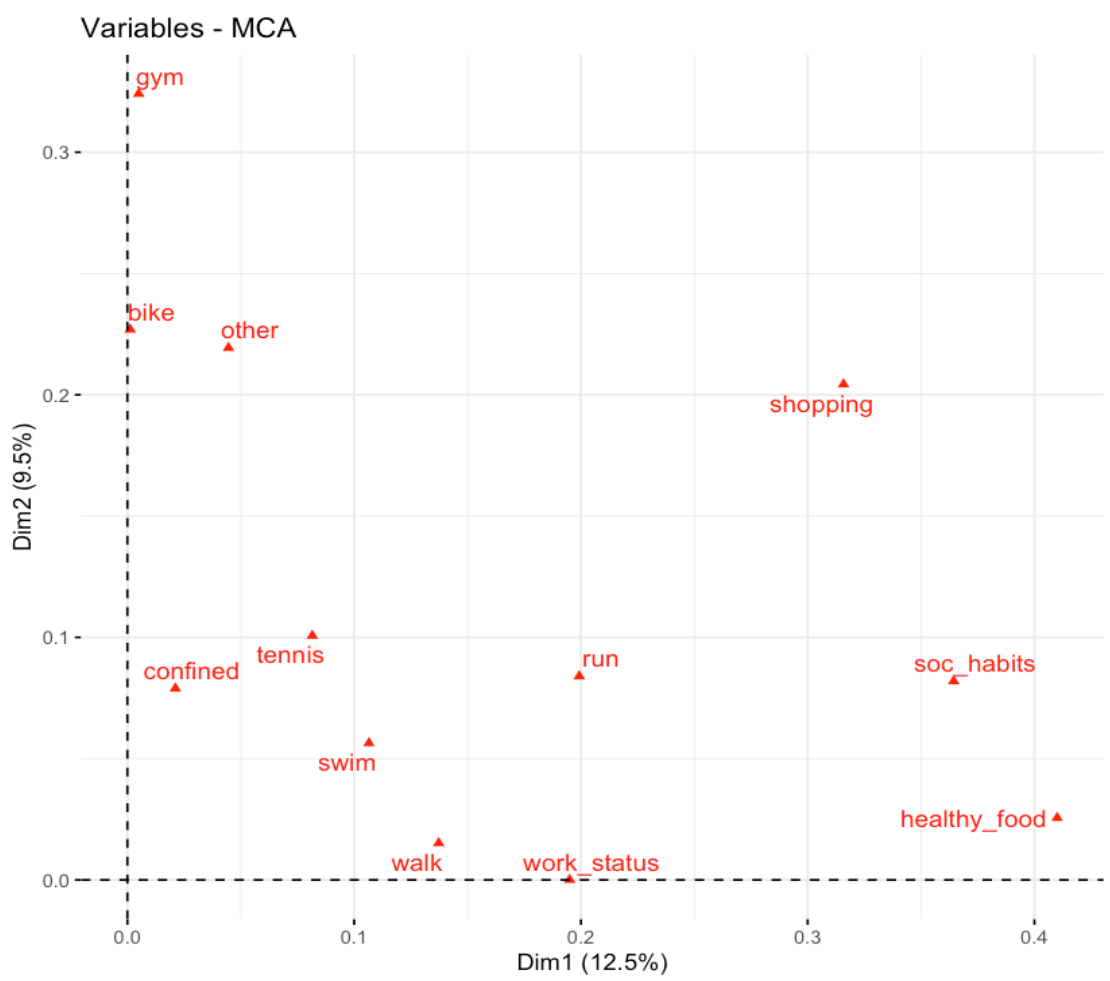

Figure 3. Multiple correspondence analysis: Variable's representation

Source: Own elaboration.

The plot in Figure 3 helps to identify variables that are the most correlated with each dimension. The squared correlations between variables and dimensions are used as coordinates.

It can be seen that the variables of work status, walk, and healthy food, are the most correlated with dimension 1 . 
Similarly, the variables in the graph cited as confined, gym, and bike are the most correlated with dimension 2 .

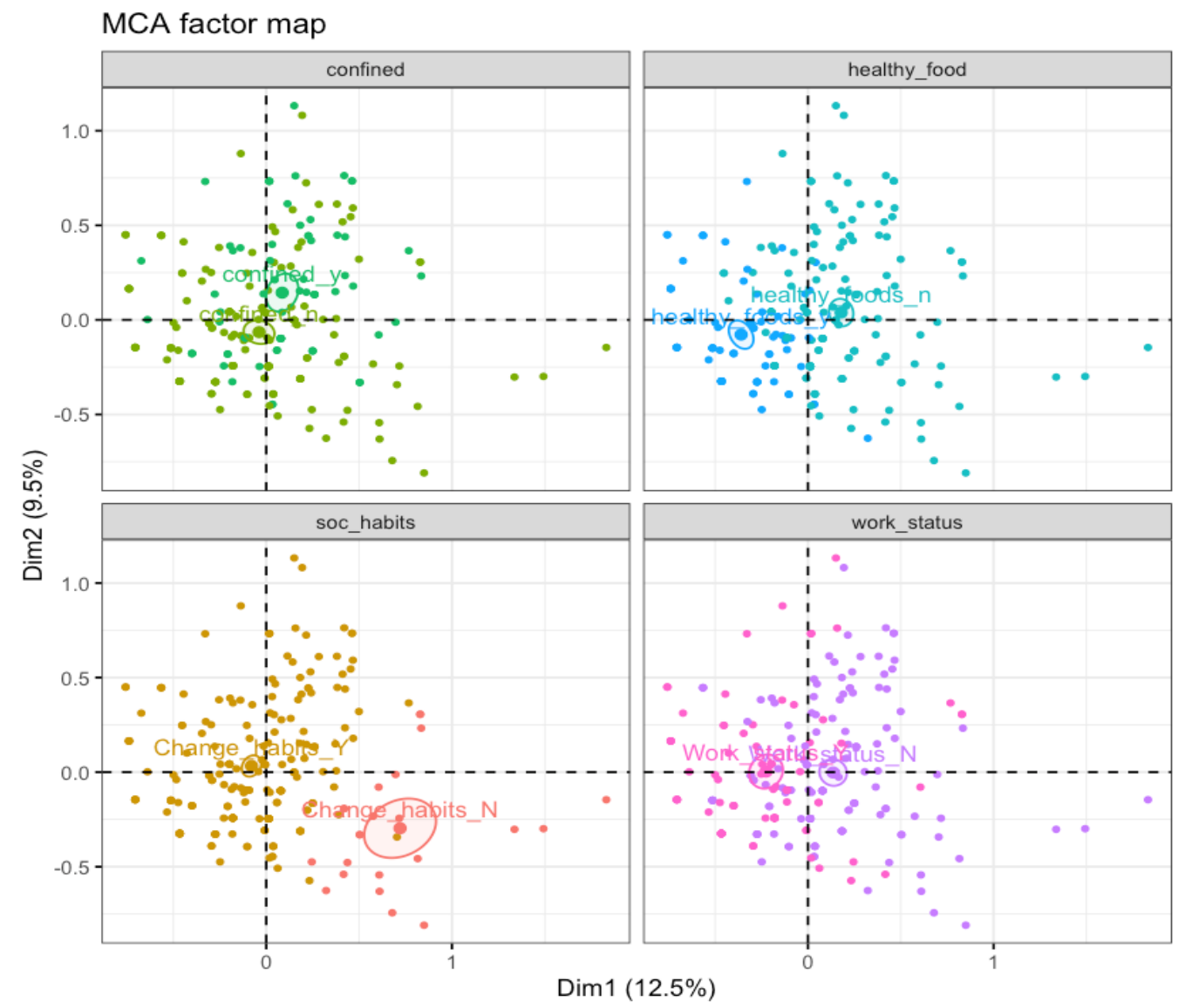

Figure 4. MCA factor map 1

Source: Own elaboration.

As shown in Figure 4, the variables studied on this plot include confined, social habits, eating habits, and work status. Row points with similar profiles are closed on the factor map. The same holds true for column points. The plot above shows the relationships between variable categories. The plot can be interpreted as follows:

- Variable categories with a similar profile are grouped together.

- Negatively correlated variable categories are positioned on opposite sides of the plot origin (opposed quadrants).

- The distance between category points and the origin measures the quality of the variable category on the factor map. Category points that are far away from the origin are well represented on the factor map. 


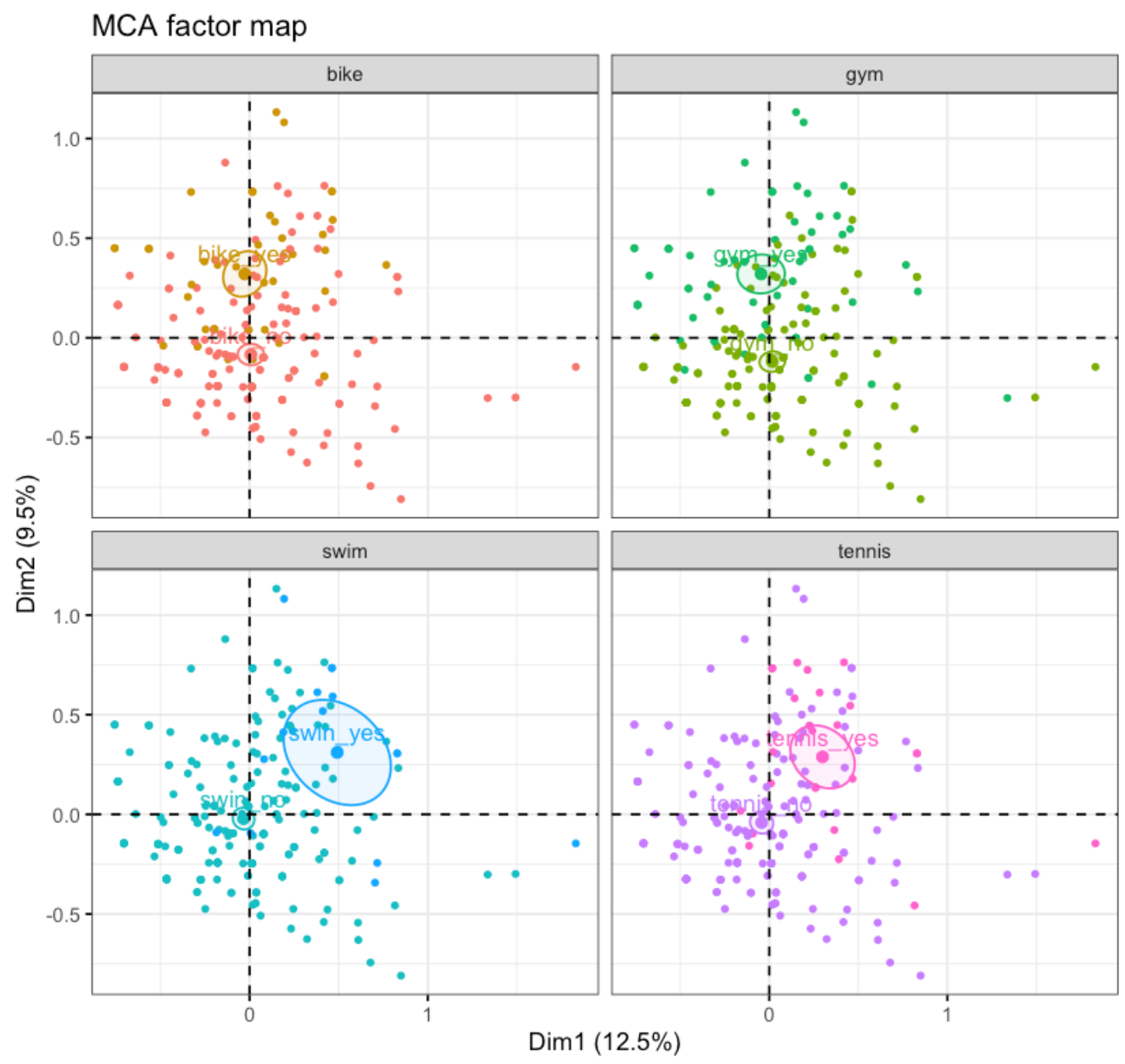

Figure 5. MCA factor map 2

Source: Own elaboration.

As it is shown in Figure 5, the variables studied on this plot include bike, gym, swim, and tennis. Activities like swim, gym, and tennis are represented much more negatively than bike due to the pandemic-related prohibition for people to be inside or in spaces with a lot of people. 


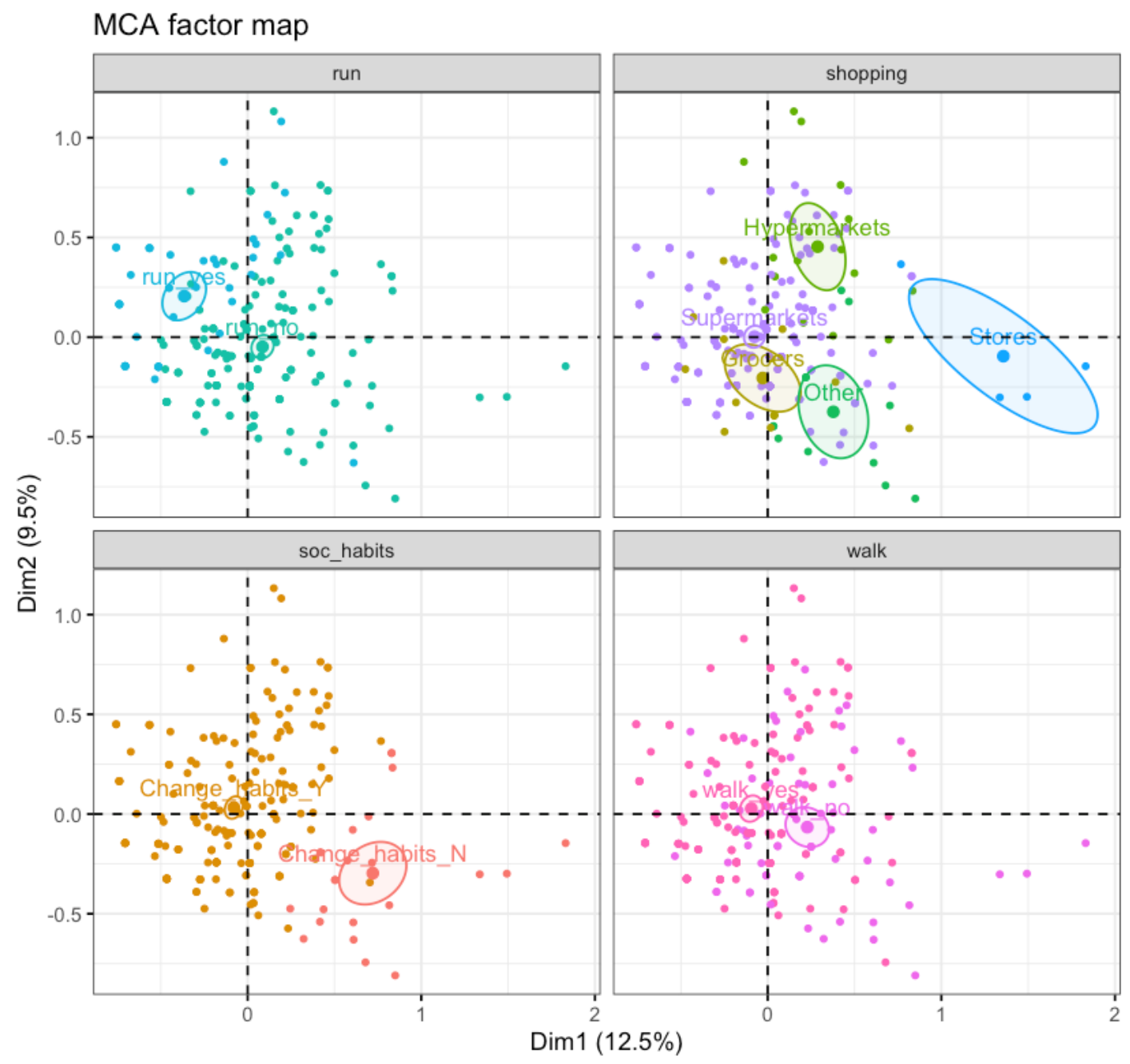

Figure 6. MCA factor map 3

Source: Own elaboration.

As shown in Figure 6, the variables studied on this plot include social habits, run, walk, and shopping habits. The plot above shows the relationships between the variable categories and can be interpreted as follows:

- The majority is represented by those individuals who have changed their social habits due to the pandemic, and the most popular activity is walking followed by running.

- In food shopping habits, hypermarkets and supermarkets are the most popular.

\section{Conclusions}

According to our analysis, the majority of the consumers in the area of Léon have changed their social, buying, and eating habits due to the pandemic. They tend to not go out so much with their family or with other people; they tend to change their consumption habits in eating healthier and buying more food online.

According to consumers they have changed their social and eating habits due to the pandemic. They are much more careful on the manner of buying food and consuming it. They consume more outdoor probably due to COVID-19 and because they stay at home for long periods of time. They are eating fewer snacks and prefer fruits. They tend to eat healthier, consume more vegetables, and take vitamin supplements.

The nearness of the supermarket is the main driving factor to shop in a physical store. Convenience, competitive prices, and variety are also found to play a major role. These findings suggest that the option of shopping for food online should be promoted in rural zones or urban places lacking brick-and-mortar stores.

Mercadona is the most popular store among consumers due its pricing. Carrefour and Amazon are the sites from which most online food shoppers buy their food. The third place was devoted to El Corte Inglés. Meanwhile, 
Leclerc, Mas y Mas, Alimerka, and DIA have almost the same popularity status, according to our findings, and are less common among respondents with a low market share percentage.

The platforms that they use more frequently to consume local food are Glovo and Deliveroo. Comfort, home delivery, time saving, and not being exposed to the virus are the main reasons motivating shoppers to buy food online. The health of other consumers and the health of grocery store workers are the main concerns for buying food in a physical establishment. The respondents of the city of Léon in Spain buy more food online, buy in less crowded stores and some have started using home-prepared food delivery.

\section{Recommendations}

Based on the results of this study, the recommendations are the following.

To remain competitive in the offline market, retailers should adopt a strategy that is price-oriented while preserving the same quality of products and services. Such an adoption will differentiate them effectively against their competitors.

The fear of being infected with the virus, limited time, long queues, and impulsive buying are the major barriers for shoppers from choosing physical stores. The solution to such issues is in increasing the number of cashiers in rush hours and in using these issues to promote online food shopping, so time-constrained consumer groups can enjoy their shopping while saving their time and making wise purchases.

Online food shopping is in its infancy in Spain. However, retailers should provide this service in their sites even if it is not currently profitable because this new shopping channel has the potential to take off as an alternative to traditional food shopping.

Online websites should be designed and segmented according to age, gender, and monthly income. Moreover, websites need to be adapted to mobiles due to the fact that in Spain, mobiles are the most used tool to browse and shop online.

Marketers may investigate which type of food products can be economically beneficial in selling online. They should provide discounts on buying food online or allocate new web pages for these product types.

Some actions are needed to lower the perception that of financial and psychological hazards in food shopping. Providing secured payment systems, data security, and privacy policies are the major recommendations to gain customers' trust and confidence in this e-service and build a brand equity that may result in more market penetration.

\section{References}

Arppe, A. (2008). Univariate, bivariate, and multivariate methods in corpus-based lexicography-a study of synonymy. $\mathrm{PhD}$ Thesis, University of Helsinki, Finland. Retrieved from http://www.ling.helsinki.fi/ aarppe/Publications/Arppe_Dissertation_Final_Print.pdf

Asociacion de empresarios y supermercados ecologicos. (2019). El Ministerio de Agricultura destaca el crecimiento del sector ecológico en España. Retrieved from http://aeseco.es/el-ministerio-de-agriculturadestaca-el-crecimiento-del-sector-ecologico-en-espana/

B2 Publicidad. (2019). Los consumidores veggies, un nicho en expansión. Retrieved from https://b2publicidad.com/consumidores-veggies-un-nicho-en-expansion/

Bell, J. (2005). Doing your research project: A guide for first time researchers in education, health and social science. Maidenhead: Open University Press.

Berry, E. (2020). Buy fresh, buy local. Retrieved from http://www.leonsgourmetgrocer.com/produce.html

Bill, R. (2011). Downtown and Business District Market Analysis (3rd ed). University of Wisconsin-Extension. Retrieved from https://fyi.uwex.edu/downtown-market-analysis/

Brand Equity. (2020). Future shock: 25 food trends post covid-19. Retrieved from https://brandequity.economictimes.indiatimes.com/news/marketing/future-shock-25-food-trends-post-covid$19 / 75590741$

Burgess, T. F. (2001). A general introduction to the design of questionnaires for survey research. Leeds University, England. Retrieved from http://iss.leeds.ac.uk/downloads/top2.pdf

Couper, M. P., Blair, J., \& Triplett, T. (1999). A Comparison of Mail and E-mail for a Survey of Employees in U.S. Statistical Agencies. Journal of Official Statistics. Retrieved from http://myberwyn.org/triplett/statcan.pdf 
Curtis, K. R. (2008). Conducting Market Research Using Primary Data. Department of Resource Economics, University of Nevada, Reno, USA. Retrieved from http://valueaddedag.org/nichemarkets/07conductingmarketresearch.pdf

De Leeuw, E. D., Hox, J. J., \& Dillman, D. A. (2008). International Handbook of Survey Methodology. Retrieved from http://joophox.net/papers/SurveyHandbookCRC.pdf

DeBroff, S. (2020). How COVID-19 Has Impacted Consumer Food Habits. Retrieved from https://www.foodmanufacturing.com/consumer-trends/blog/21133823/how-COVID19-has-impacted-consu mer-food-habits

Diener-West, M. (2008). Use of the Chi-Square Statistic. Johns Hopkins Bloomberg School of Public Health. Retrieved from http://ocw.jhsph.edu/courses/FundEpiII/PDFs/Lecture17.pdf

Dillman, D. A. (2007). Mail and internet surveys: The tailored design method (2nd ed.). New York: Wiley.

E-commerce Delivery Compass. (2020). Retrieved from https://www.sendcloud.com/wp-content/uploads/2020/09/Sendcloud-E-commerce-Delivery-Compass-20202021-EU.pdf

elEconomista. (2014). La era de la tecnología. Retrieved from https://www.eleconomista.es/tecnologia/noticias/6315309/12/14/La-tercera-revolucion-industrial-los-robots -sustituiran-al-hombre-y-la-desigualdad-sera-mayor.html

Euromonitor International. (2016). Grocery Retailers in Spain. Retrieved from http://www.euromonitor.com/grocery-retailers-in-spain/report

FAO. (2015). Global and regional food consumption patterns and trends. Retrieved from http://www.fao.org/3/AC911E/ac911e05.htm

Felix, I., Martin, A., Mehta, V., \& Mueller, C. (2020). Food supply chain, disruptions and implications from COVID-19. Retrieved from https://www.mckinsey.com/industries/consumer-packaged-goods/our-insights/us-food-supply-chain-disrupti ons-and-implications-from-COVID-19\#

Ferrer, G. G. (2016). Investigación comercial (Chap. 1: Concepto y aplicación de la investigación comercial, pp. 31-38. Chap. 5: El cuestionario, pp. 101-136. Chap. 7: Análisis univariante, pp. 162-175. Chap. 8: Análisis bivariante, pp. 193-205).

Fishbein, M., \& Ajzen, I. (1975). Belief, Attitude, Intention, and Behaviour: An Introduction to Theory and Research. Retrieved from https://www.researchgate.net/publication/233897090_Belief_attitude_intention_and_behaviour_An_introdu ction_to_theory_and_research

Food Retail. (2020). $\quad$ Retrieved from https://www.foodretail.es/food/productores-venta-alimentos-proximidad-plataforma-mercado-local_0_1436 856315.html

Fricker, R. D. Jr., \& Schonlau, M. (2002). Advantages and Disadvantages of Internet Research Surveys: Evidence from the Literature. Field Methods, 14(4), 347-367. https://doi.org/10.1177/152582202237725

Fridah, M. (2002). Sampling in Research. Retrieved from http://indiana.edu/ _educy520/sec5982/week_2/mugo02sampling.pdf

González, L. (2020). Así ha cambiado el consumo de alimentos en España tras el confinamiento. Retrieved from https://www.traveler.es/gastronomia/articulos/estudio-consumo-alimentos-despues-confinamiento-basque-c ulinary-center/18391?utm_medium=picks.es.20200624\&utm_source=email\&utm_content=article\&utm_ca mpaign $=$ picks

Hair, J. F., Anderson, R. E., Tatham, R. L., \& Black, W. C. (1998). Multivariate data analysis (Chap. 1 Types of Multivariate techniques, pp. 14-16).

Heron, E. (2009). Analysis of Variance - ANOVA. Retrieved from https://www.tcd.ie/medicine/neuropsychiatric-genetics/assets/pdf/2009_3_ANOVA.pdf

Honeycutt, E. (2017). Why buy local food? It is healthier for you and for the environment. Retrieved from https://foodrevolution.org/blog/why-buy-local-food/

Hox, J. J., \& Boeije, H. R. (2005). Data collection, primary vs. secondary. Encyclopedia of Social Measurement, 
593-599. https://doi.org/10.1016/B0-12-369398-5/00041-4

Jan-Benedict, E. M. (1993). Food Consumption Behavior. In W. F. Van Raaij \& J. B. Gary (Eds.), European Advances in Consumer Research (Volume 1, Association for Consumer Research, pp. 401-409). Retrieved from https://www.acrwebsite.org/volumes/11478/volumes/e01/E-01

Kantar World Panel. (2014). Shopping for groceries: What if online retail was bigger than Tesco? Retrieved from https://www.kantarworldpanel.com/dwl.php?sn=news_downloads\&id=267

Kothari, C. R. (2004). Research Methodology: Methods and Techniques (2nd ed.). New Age International (P) Ltd. University of Rajasthan, Jaipur, India. Retrieved from http://www2.hcmuaf.edu.vn/data/quoctuan/Research\%20Methodology\%20-\%20Methods\%20and\%20Techn iques\%202004.pdf

Koufaris, M., Kambil, A., \& LaBarbera, P. A. (2002). Consumer behaviour in Web-based commerce: and empirical study. International Journal of Electronic Commerce, 6, 115-138. https://doi.org/10.1080/10864415.2001.11044233

Krosnick, J. A., \& Presser, S. (2009). Question and Questionnaire Design. Handbook of Survey Research (2nd ed.). Retrieved from $\mathrm{http}: / /$ courses.ischool.berkeley.edu/i271b/f12/readings/2010HandbookSurveyResearch.pdf.

Kumar, R. (2011). Research Methodology a Step-By-Step Guide for Beginners (2nd ed.). Retrieved from http://www.sociology.kpi.ua/wp-content/uploads/2014/06/Ranjit_Kumar-Research_Methodology_A_Step-b y-Step_G.pdf

Lim, H., \& Dubinsky, A. J. (2004). Consumers' perceptions of e-shopping characteristics: An expectancy-value approach. The Journal of Services Marketing, 18(6), 500-513. https://doi.org/10.1108/08876040410561839

Luckstead, J., \& Snell, H. (2020). Agriculture and the Food Supply during the Coronavirus Pandemic, Applied Economic Perspectives and Policy.

Maas, A. (2020). It's time to consider your post-COVID marketing strategy. Retrieved from https://www.foodbeverageinsider.com/market-trends-analysis/its-time-consider-your-post-covid-marketingstrategy

Maxwell, A. E. (1971). Analyzing Qualitative Data (4th ed.). Chapman and Hall Ltd. Library of Congress Catalog Card Number 75-10907.

Meiselman, H. L. (2019). Food consumption. In Bellisle, F. (Ed.), Context: The Effects of Environment on Product Design and Evaluation (Chap. 10.3.1 The "Satiety Cascade", pp. 209-225).

Mercasa. (2020). El sector agroalimentario después de la COVID-19. Retrieved from https://www.mercasa.es/

Ministerio de Agricultura, \& Pesca y Alimentación. (2020a). Buscador de plataformas de venta de alimentos de proximidad. Retrieved from https://www.alimentosdespana.es/es/alimentos-de-proximidad/.

Ministerio de Agricultura, \& Pesca y Alimentación. (2020b). Informe del consumo de alimentación en España. Retrieved from https://www.mapa.gob.es/es/alimentacion/temas/consumotendencias/informe2019_vf_tcm30-540250.pdf

Ministro de Agricultura, \& Pesca y Alimentación. (2020). Plataformas de venta de alimentos de proximidad. Retrieved from http://www.alimentacion.es/es/

Moreiras, G. V. (2015). Alimentación y sociedad en la España del siglo XXI. Retrieved from file:///C:/Users/34644/Downloads/Estudio_Alimentaci_n_y_Sociedad_en_la_Espa_a_del_s_XXI.pdf

Mosquera, L. (2020, 22 Septiembre). Estudio Kantar: el sector del gran consumo mantiene su crecimiento. Retrieved from https://www.agronegocios.es/estudiokantar-el-sector-del-gran-consumo-mantiene-su-crecimiento/

MPAC. (2017). Principales Canales de Compra de Alimentos. Presente y Futuro. Retrieved from https://www.mesaparticipacion.com/files/110_180724_Articulo_opini_n_MM_Canales_de_compra.pdf

O'Leary, F. (2020). How Covid-19 has changed consumer food trends. Retrieved from https://www.farmprogress.com/marketing/how-covid-19-has-changed-consumer-food-trends

Organización de Consumidores y Usuarios. (2019). El 36\% de los españoles utiliza Apps de comida a domicilio $y$ solo el $10 \%$ de estos lo hace a menudo \#. Retrieved from https://www.ocu.org/organizacion/prensa/notas-de-prensa/2019/appscomida051119 
Perea, F. (2020). Los alimentos frescos y de proximidad fueron la tendencia en 2019. Retrieved from https://revistamercados.com/los-alimentos-frescos-y-deproximidad-fueron-la-tendencia-en-2019/

Poelman, M. P., \& Ingrid, H. M. (2019). Food choices in context (Part; 7.5.1, Chp. 7, pp. 143-168). https://doi.org/10.1016/B978-0-12-814495-4.00007-6

Postnord. (2019). E-commerce-in-Europe. $\quad$ Retrieved from http://www.postnord.fi/globalassets/suomi/raportit/e-commerce-in-europe-2016.pdf

Raijas, A., \& Tuunainen, V. P. (2001). Critical factors in electronic grocery shopping. The International Review of Retail, Distribution and Consumer Research, 11, 255-265. https://doi.org/10.1080/713770596

Rajasekar, S., Philominathan, P., \& Chinnathambi, V. (2013). Research methodology. Retrieved from https://arxiv.org/pdf/physics/0601009.pdf.

Rand Corporation. (2020). Consumer behaviours and attitudes to food. Retrieved from https://www.rand.org/randeurope/research/projects/consumer-behaviours-and-attitudes-to-food.html

Rodríguez, M. (2019). Comercio electrónico: Tendencias en los hábitos de compra, el marco regulatorio y los valores éticos. Retrieved from https://www.mercasa.es/media/publicaciones/257/Comercio_electronico_tendencias.pdf

Statista. (2020). Share of individuals who purchased food or groceries online in Spain from 2009 to 2019. Retrieved from https://www.statista.com/statistics/700640/share-of-individuals-who-purchased-groceries-online-in-spain/

Therrien, J. (2020). Consumer behaviour trends: Food and beverage industry and Covid-19. Retrieved from https://www.thundertech.com/blog/July-2020/Consumer-Behavior-Trends-Food-and-Beverage-Industry

Ticbeat. (2020). Los españoles gastamos más online y consumimos más local desde el inicio de la pandemia. Retrieved from https://www.ticbeat.com/tecnologias/resultados-conclusiones-estduio-facebookdeloitte/?utm_medium=pick s.es.20201005\&utm_source $=$ email\&utm_content $=$ article\&utm_campaign $=$ picks

Van de Ligt, J. (2019). Food in the 21st Century: Challenges in the Food System. Retrieved from https://www.foodsafetymagazine.com/enewsletter/food-in-the-21st-century-challenges-in-the-food-system/

Varela, P. M. (2020). Soluciones para comer sano y rico cuando no tienes tiempo. Retrieved from https://business.vogue.es/tendencias/galerias/comida-saludable-empresas-alimentacion-internet-delivery/12 0/image/1857

Williams, L. J., \& Abdi, H. (2010). Post-Hoc Comparisons. In S. Neil (Ed.), Encyclopedia of Research Design. Retrieved from https://www.utdallas.edu/ herve/abdi-PostHoc2010-pretty.pdf

\section{Copyrights}

Copyright for this article is retained by the author, with first publication rights granted to the journal.

This is an open-access article distributed under the terms and conditions of the Creative Commons Attribution license (http://creativecommons.org/licenses/by/4.0/). 